\title{
Nitrate Reductase from Anaerobically Grown Rhizobium japonicum
}

\author{
By R. M. DANIEL* AND J. GRAY \\ Department of Cell Biology, University of Glasgow, $G \mathrm{I} 28 Q Q$
}

(Received 6 October 1975; revised 6 May 1976)

\begin{abstract}
SUMMARY
The activity of nitrate reductase in Rhizobium japonicum is controlled by oxygen tension, and not by nitrate. The enzyme from $R$. japonicum grown anaerobically in the presence of nitrate resembles that from bacteroids in having a molecular weight of about 69000 daltons; the enzyme from aerobically grown cells has a molecular weight of about 170000 daltons. Both types of enzyme have similar $K_{\mathrm{m}}$ values, but differ in their sensitivity to $\mathrm{KCN}$.
\end{abstract}

\section{INTRODUCTION}

Free-living Rhizobium japonicum strain 505 (Wisconsin) grown anaerobically with nitrate as an electron acceptor has a number of features in common with the symbiotic, $\mathrm{N}_{\mathbf{2}^{-}}$ fixing bacteroid form of this organism, including a nitrate reductase level which is about five times that found in free-living $R$. japonicum grown aerobically (Daniel \& Appleby, 1972). Since the ability of Rhizobium to fix $\mathrm{N}_{2}$ depends upon environmental conditions, rather than being a unique feature of an obligate symbiosis with legumes (Pagan et al., 1975; Kurz \& LaRue, 1975; McComb, Elliot \& Dilworth, 1975), a study of the effect of environmental conditions is of some interest. In particular, a study of nitrate reductase may be important in understanding $\mathrm{N}_{2}$ fixation, since there is evidence for a common genetic determinant for nitrate reductase and nitrogenase (Kondorosi et al., 1973), and they may share a common subunit (Evans \& Russel, 197I). Some aspects of the nitrate reductase from both the aerobically grown (Lowe \& Evans, 1964) and bacteroid (Evans, 1954; Cheniae \& Evans, 1959; Kennedy, Rigaud \& Trinchant, 1975) forms of $R$. japonicum have been studied, and this paper presents complementary work on the enzyme from cells grown anaerobically.

\section{METHODS}

Growth and preparation of free-living bacteria and bacteroids. Rhizobium japonicum strain CC705 (Wisconsin 505) was grown as described by Daniel \& Appleby (1972). Bacteroids were isolated and purified from $\mathrm{N}_{2}$-fixing soybean root nodules (Glycine max Merr., cv. Lincoln) inoculated with $R$. japonicum strain $\mathrm{CC} 705$ and grown as described by Appleby (1969a).

Preparation of nitrate reductase. All operations were carried out at 0 to $4{ }^{\circ} \mathrm{C}$, using buffers flushed with $\mathrm{N}_{2}$ or argon. Anaerobic conditions were maintained where necessary, by using a stream of $\mathrm{N}_{2}$ or argon.

Washed organisms, suspended in $0 . \mathrm{I}$ M-sodium-potassium phosphate buffer $\mathrm{pH} 6.8$, were ruptured in a French pressure cell at about $10^{8} \mathrm{~Pa}$. The exuded material was centrifuged at $10000 \mathrm{~g}$ for $15 \mathrm{~min}$; and then the supernatant was re-centrifuged at $250000 \mathrm{~g}$ for $\mathrm{I} \mathrm{h}$.

* Present address: School of Science, University of Waikato, Hamilton, New Zealand. 
The final supernatant was concentrated, where necessary, by pressure filtration over a Diaflow PM ro membrane (Amicon Corporation, High Wycombe, Buckinghamshire). The pellet from the second centrifugation was washed once in $0.1 \mathrm{M}$-sodium-potassium phosphate buffer $\mathrm{pH} 6.8$, and the membrane particles were resuspended to a final protein concentration of 30 to $50 \mathrm{mg} \mathrm{ml}^{-1}$.

Assay of nitrate reductase. In the presence of nitrite reductase, nitrate reductase was assayed by nitrate removal, using a method for nitrate determination based on that of Szekely (1967). Assays were run in duplicate in conical $15 \mathrm{ml}$ centrifuge tubes at $25^{\circ} \mathrm{C}$. When using electron donors other than dithionite, the tubes were stoppered and the reaction was run under argon. The reaction mixture contained $100 \mathrm{mM}$-sodium-potassium phosphate buffer $\mathrm{pH} 6 \cdot 8,70 \mu \mathrm{g}$ methyl viologen $/ \mathrm{ml}$ and $\mathrm{r} \cdot 2 \mathrm{~mm}^{-\mathrm{KNO}_{3}}$. The enzyme suspension in $0 . \mathrm{I} \mathrm{ml}$ was added to $0.5 \mathrm{ml}$ reaction mixture, and the reaction was started by adding $0 . \mathrm{I} \mathrm{ml}$ $30 \mathrm{~mm}-\mathrm{Na}_{2} \mathrm{~S}_{2} \mathrm{O}_{4}$. After incubating for 5 to $30 \mathrm{~min}$, the reaction was stopped by agitating the tube on a vortex mixer for about $90 \mathrm{~s}$, and then immediately adding $0.5 \mathrm{ml} 20 \%(\mathrm{v} / \mathrm{v})$ trichloroacetic acid. The precipitated protein was centrifuged for $15 \mathrm{~min}$ at $6000 \mathrm{~g}$, the supernatant was decanted and cooled to $0^{\circ} \mathrm{C}$, about $2 \mathrm{mg} \mathrm{NaCl}$ was added, and $6 \mathrm{ml}$ icecold diaminodiphenylsulphone reagent (see below) was added dropwise with thorough mixing and cooling in an ice bath. When the addition was complete, the tube was kept in ice until the reagent had been added to all tubes. The mixtures were then incubated, with standards, in a water bath at $15{ }^{\circ} \mathrm{C}$ for $\mathrm{I} h$ and their extinctions at $6 \mathrm{IO} \mathrm{nm}$ were read against a reagent blank. The time and temperature of this incubation were critical. Shorter incubations and/or lower temperatures gave greater sensitivity but erratic results; longer incubations and/or higher temperatures gave linear results over a wider range of nitrate concentrations but lower sensitivity.

For the diaminodiphenylsulphone reagent, $50 \mathrm{mg}$ diphenylamine and $2 \mathrm{~g} p$-diaminodiphenylsulphone were dissolved in $225 \mathrm{ml}$ double-distilled water, $600 \mathrm{ml} \mathrm{I} 8 \mathrm{M}-\mathrm{H}_{2} \mathrm{SO}_{4}$ (BDH Aristar grade) was added slowly, the solution was cooled, and $100 \mathrm{ml} 9 \mathrm{M}^{-} \mathrm{H}_{3} \mathrm{PO}$ was added. The mixture was then made up to I 1 with $18 \mathrm{M}-\mathrm{H}_{2} \mathrm{SO}_{4}$, and was colourless or pale blue. An intense blue colour indicated excessive contamination with nitrate.

In the absence of nitrite reductase, it was more convenient to assay nitrate reductase by nitrite production. The reaction mixture and procedures were as described above, except that after stopping the reaction by agitating the tube on a vortex mixer, nitrite was determined as described by Nicholas \& Nason (I957).

In whole cells, nitrate reductase was determined as described by Daniel \& Appleby (1972).

Molecular-weight determination and partial purification of soluble nitrate reductase. A portion ( $3 \mathrm{ml}$ ) of the $250000 \mathrm{~g}$ supernatant containing I Io to I $30 \mathrm{mg}$ protein was applied to an $85 \times 2.5 \mathrm{~cm}$ column of Sephadex G-I50 (Pharmacia). The column was eluted with $\mathrm{N}_{2}$ saturated $25 \mathrm{~mm}$-sodium-potassium phosphate buffer $\mathrm{pH} 6.8$, and $5 \mathrm{ml}$ fractions were collected under $\mathrm{N}_{2}$. All procedures were carried out at 0 to $4{ }^{\circ} \mathrm{C}$. The column was calibrated for molecular-weight determinations using crystalline proteins (mol. wt. 247000 to 12000 daltons) as described by Andrews (1964). Cytochrome $c$ (Appleby 1969 $b$; Daniel \& Appleby 1972), and nitrite reductase when present (Daniel \& Appleby, 1972; Daniel, unpublished results), were used as internal molecular-weight markers.

\section{RESULTS AND DISCUSSION}

The level of activity of nitrate reductase in free-living $R$. japonicum depended on the $\mathrm{O}_{2}$ tension (Fig. I), as suggested by earlier work (Daniel \& Appleby, 1972). This explains the 


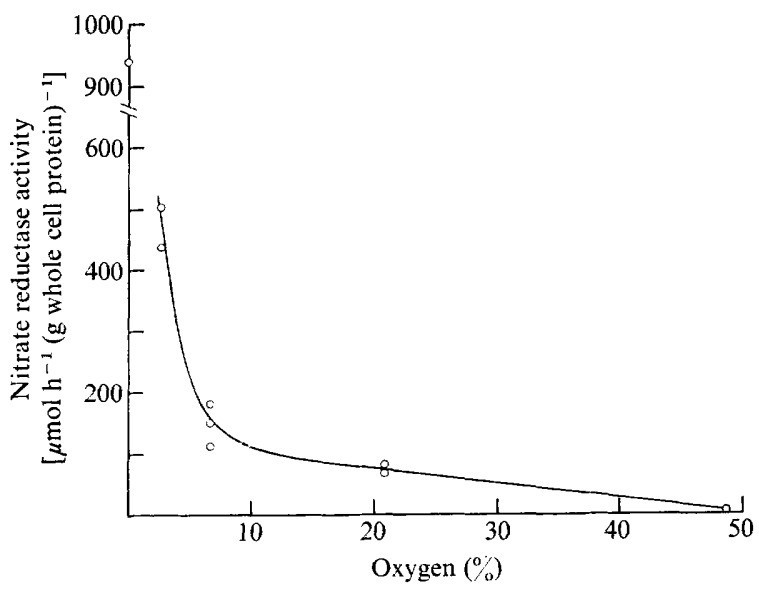

Fig. I. The effect of oxygen tension during growth on the nitrate reductase activity of whole cells of $R$. japonicum. Cells were grown and nitrate reductase activity determined as described by Daniel \& Appleby (1972). The point for zero $\mathrm{O}_{2}$ was determined from cells grown only in the presence of $6 \mathrm{~mm}$ $\mathrm{KNO}_{3}$. Cells grown at all other $\mathrm{O}_{2}$ tensions gave identical levels of nitrate reductase activity in both the presence and absence of $6 \mathrm{~mm}-\mathrm{KNO}_{3}$.

Table I. Distribution and purification of nitrate reductase in anaerobically-and aerobically-grown $R$. japonicum

Assays were carried out anaerobically by measuring the removal of nitrate as described in Methods.

\begin{tabular}{|c|c|c|c|c|}
\hline & $\begin{array}{l}\text { Vol. } \\
\text { (ml) }\end{array}$ & $\begin{array}{l}\text { Total protein } \\
\text { (mg) }\end{array}$ & $\begin{array}{l}\text { Specific activity } \\
{\left[\text { nmol } \mathrm{NO}_{3}^{-}\right.} \\
\text {removed min } \\
{\left.\text { (mg protein })^{-1}\right]}^{-1}\end{array}$ & Purification \\
\hline \multicolumn{5}{|l|}{ Anaerobically-grown cells } \\
\hline Cell-free extract & I6 & I4IO & 74 & $\mathbf{I}$ \\
\hline Membrane particles & $6 \cdot 2$ & 552 & 34 & - \\
\hline Supernatant & $12 \cdot 2$ & 537 & 127 & $\mathbf{I} \cdot 7$ \\
\hline Sephadex G-I 50 eluate (peak fraction) & 6 & $1 \cdot 6$ & 650 & $8 \cdot 8$ \\
\hline \multicolumn{5}{|l|}{ Aerobically-grown cells } \\
\hline Cell-free extract & 15 & 1040 & 14.3 & I \\
\hline Membrane particles & $6 \cdot 8$ & 273 & $8 \cdot I$ & - \\
\hline Supernatant & 13.4 & 555 & 26 & $\mathrm{I} \cdot 8$ \\
\hline Sephadex G-I 50 eluate (peak fraction) & 6 & 0.8 & 80 & $5 \cdot 6$ \\
\hline
\end{tabular}

similar high levels of activity of the enzyme in the anaerobically grown and bacteroid forms of $R$. japonicum (Daniel \& Appleby, 1972), since the $\mathrm{O}_{2}$ tension within the root nodule is very low (Appleby I962, I969c).

As previously reported for aerobically grown cells and the bacteroid form of $R$. japonicum (Cheniae \& Evans, I959; Lowe \& Evans, I964; Kennedy et al., I975), nitrate reductase activity was present in both particulate and soluble fractions of anaerobically grown cells (Table I). Although the ratio of total soluble nitrate reductase activity to total membranebound activity was 3.5 for anaerobically grown cells and 6.5 for aerobically grown cells, this difference may not be significant, particularly as the ratios of the specific activities of the soluble and membrane-bound fractions in the two types of cells are the same. Any variation in the fractionation characteristics of the two types of cells could alter the relative yields of the membrane fraction.

Only dithionite is an effective reductant of the soluble partially-purified nitrate reductase 
Table 2. Effect of different electron donors on the activity of the partially-purified nitrate reductase from anaerobically-grown $R$. japonicum

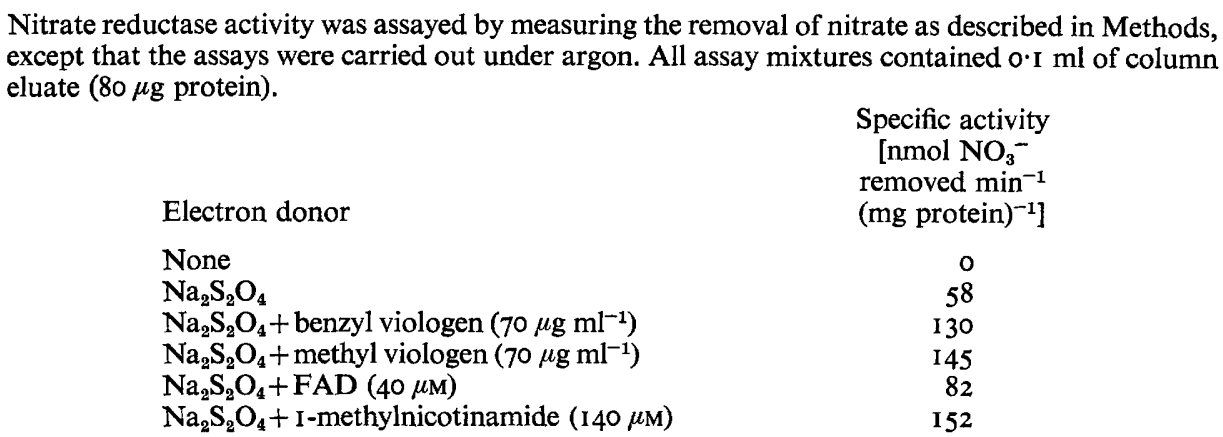

$\mathrm{NaBH}_{4}$, succinate, NADH and NADPH all gave zero specific activity in both the presence and absence of the above carriers.

from anaerobically grown $R$. japonicum (Table 2). The effectiveness of I-methylnicotinamide as an electron donor (whose use we have not seen described before) is useful in situations where a colourless reaction mixture is required, e.g. in relieving $\mathrm{CO}$ inhibition by light.

The elution pattern from Sephadex G-I50 columns showed that only a single nitrate reductase was present in each of the three types of cell, and indicated that the nitrate reductase from anaerobically grown cells had the same molecular weight as that from bacteroids (about 69000 daltons). The molecular weight of the nitrate reductase from aerobically grown cells was much higher (about 170000 daltons), which disagrees with the work of Kennedy et al. (1975) who found that the nitrate reductase from bacteroids was of the same molecular weight as that from aerobically grown cells, i.e. 66000 to 70000 daltons. This may be due to the lower aeration applied during growth of aerobically grown cells by Kennedy et al. (1975), or to their use of sonication for cell breakage. Our attempts to induce low molecular weight nitrate reductase by growth under low $\mathrm{O}_{2}$ tension were only partially successful, and other treatments, such as altering the nitrate levels in the growth medium or treating the $250000 \mathrm{~g}$ supernatant, were unsuccessful. Application of a mixture of $250000 \mathrm{~g}$ supernatants from aerobically and anaerobically grown cells to the Sephadex column yielded two peaks at elution volumes corresponding to about 70000 daltons and 170000 daltons, as expected.

The soluble nitrate reductase from anaerobically grown cells had a very similar $K_{\mathrm{m}}$ to that from aerobically grown cells; values were $\mathrm{IO} \mu \mu_{\mathrm{M}}$ and $9 \mathrm{I} \mu \mathrm{M}$ respectively. These values are somewhat lower than the $330 \mu \mathrm{M}$ for aerobically grown cells and higher than the I $6 \mu \mathrm{M}$ for bacteroids reported by Kennedy et al. (1975).

The inhibition of nitrate reductase by cyanide was assayed by measuring nitrate removal. $\mathrm{KCN}$ at $0.55 \mathrm{mM}$ inhibited nitrate reductase from aerobically grown cells by about $50 \%$, but had no effect on that from anaerobically grown cells. At $5.5 \mathrm{~mm}$, it totally inhibited the former but resulted in only $25 \%$ inhibition of the latter. Assays for the inhibition of nitrate reductase by $\mathrm{CO}$ were carried out in closed test-tubes under argon, using I-methylnicotinamide instead of methyl viologen. At 3.6 $\mu \mathrm{M}, \mathrm{CO}$ inhibited nitrate reductase from aerobically grown cells by $80 \%$ and that from anaerobically grown cells by $90 \%$. In the presence of light, the inhibition was only $35 \%$ in both cases, indicating the involvement of a haemoprotein.

As noted by Lowe \& Evans (1964) and Kennedy et al. (1975), nitrate reductase from 
$R$. japonicum is sensitive to air. Exposure of a $2 \mathrm{~mm}$ layer of $250000 \mathrm{~g}$ supernatant to a stream of air for $5 \mathrm{~min}$ decreased the nitrate reductase activity from anaerobically grown cells by $52 \%$, and that from aerobically grown cells by $14 \%$, compared with exposure to $\mathrm{N}_{2}$.

The similar $K_{\mathrm{m}}$ values of the nitrate reductases from aerobically and anaerobically grown cells taken together with the findings of Kennedy et al. (1975) and Lowe \& Evans (1964) suggest that the nitrate reductases from $R$. japonicum grown under different conditions (root nodule bacteroids, anaerobically and aerobically grown free-living cells) are identical. However some findings reported here $\left(\mathrm{O}_{2}\right.$ sensitivity, cyanide inhibition, and molecular weight) indicate differences between the nitrate reductases from aerobically and anaerobically grown cells. These differences may be due to sub-unit interactions.

We thank Mrs Alice Corrish for her skilled technical assistance. The work was supported by grant AG ${ }_{17} / 88$ from the Agricultural Research Council.

\section{REFERENCES}

ANDREWS, P. (1964). Estimation of the molecular weights of proteins by Sephadex gel-filtration. Biochemical Journal 91, 222-233.

APPLEBY, C. A. (1962). The oxygen equilibrium of leghaemoglobin. Biochimica et biophysica acta 60, 226-235.

APPLEBY, C. A. (1969a). Electron transport systems of Rhizobium japonicum. I. Haemoprotein P-450, other CO-reactive pigments, cytochromes and oxidases in bacteroids from $\mathbf{N}_{2}$-fixing root nodules. Biochimica et biophysica acta $\mathbf{1 7 2}, 7 \mathrm{I}-87$.

APPLEBY, C. A. (1969b). Electron transport systems of Rhizobium japonicum. II. Rhizobium haemoglobin, cytochromes and oxidases in free-living (cultured) cells. Biochimica et biophysica acta 172, 88-105.

APPLEBY, C. A. $(1969 c)$. Properties of leghaemoglobin in vivo, and its isolation as ferrous oxyleghaemoglobin. Biochimica et biophysica acta 188, 222-229.

Chentae, G. \& Evans, H. J. (1959). Properties of a particulate nitrate reductase from the nodules of the soybean plant. Biochimica et biophysica acta 35, 140-153.

Daniel, R. M. \& ApPLEBY, C. A. (1972). Anaerobic-nitrate, symbiotic and aerobic growth of Rhizobium japonicum: effects on cytochrome P-450, other haemoproteins, nitrate and nitrite reductases. Biochimica et biophysica acta 275, 347-354.

Evans, H. J. (1954). Diphosphopyridine nucleotide-nitrate reductase from soybean nodules. Plant Physiology 29, 298-301.

Evans, H. J. \& RUSSEL, S. A. (I97I). Physiological chemistry of symbiotic nitrogen fixation by legumes. In The Chemistry and Biochemistry of Nitrogen Fixation, pp. 19I-244. Edited by J. R. Postgate. London: Plenum Press.

Kennedy, I. R., Rigaud, J. \& Trinchant, J. C. (1975). Nitrate reductase from bacteroids of Rhizobium japonicum: enzyme characteristics and possible interaction with nitrogen fixation. Biochimica et biophysica acta 397, 24-35.

Kondorosi, A., Barabas, I., Svab, Z., OrosZ, L. \& SiK, T. (1973). Evidence for common genetic determinants of nitrogenase and nitrate reductase in Rhizobium meliloti. Nature, New Biology 246, 153-154.

KURz, W. G. W. \& LARUE, T. A. (1975). Nitrogenase activity in rhizobia in absence of plant host. Nature, London 256, 407-409.

Lowe, R. H. \& Evans, H. J. (1964). Preparation and some properties of a soluble nitrate reductase from Rhizobium japonicum. Biochimica et biophysica acta 85, 377-389.

McСомв, J. A., Еlliot, J. \& Dilworth, M. J. (1975). Acetylene reduction by Rhizobium in pure culture. Nature, London 256, 409-410.

Nicholas, D. J. D. \& Nason, A. (1957). Determination of nitrate and nitrite. In Methods in Enzymology, vol. 3, pp. 981-984. Edited by S. P. Colowick and N. O. Kaplan. New York: Academic Press.

Pagan, J. D., Child, J. J., ScowCrofT, W. R. \& Gibson, A. H. (1975). Nitrogen fixation by Rhizobium cultured on a defined medium. Nature, London 256, 406-407.

SZEKELY, E. (1967). Spectrophotometric determination of nitrate with $p$-diaminodiphenylsulphone and diphenylamine-p-diaminodiphenylsulphone. Talanta 14, 94I-950. 